Revista de Economia Política, vol. 35, $n^{\circ} 1$ (138), pp. 3-27, janeiro-março/2015

\title{
Overvaluation trend of the Brazilian currency in the 2000s: empirical estimation
}

\author{
ANDRÉ NASSIF \\ CARMEM FEIJÓ \\ ELIANE ARAÚJO*
}

\begin{abstract}
RESUMO: O objetivo deste artigo é discutir a tendência à supervalorização da moeda brasileira na década de 2000, apresentando um modelo econométrico para estimar a taxa de câmbio real (TCR) e que deveria ser usada como nível de referência para orientar a política econômica de longo prazo . No modelo econométrico, consideramos componentes estruturais de curto prazo e longo prazo, sendo que ambos podem ser responsáveis para explicar a tendência à sobrevalorização da moeda brasileira. Nosso exercício econométrico confirma que a moeda brasileira havia sido persistentemente sobrevalorizado ao longo de quase todo o período em análise, e sugere que o nível da taxa de câmbio real de referência de longo prazo foi alcançado em 2004. Em julho de 2014, a taxa de câmbio nominal média deveria ter sido em torno de 2,90 reais por dólar (contra uma taxa nominal de 2,22 reais por dólar observada) para atingir o real nível de referência de 2004 (média do ano). Ou seja, de acordo com nossas estimativas, em julho de 2014, o real brasileiro estava sobrevalorizado em 30,6\% em termos reais em relação ao nível de referência. Com base nestes resultados, concluímos o artigo sugerindo uma combinação de instrumentos políticos que deveriam ter sido utilizados, a fim de inverter essa tendência à sobrevalorização da taxa de câmbio, incluindo uma meta para se chegar, no médio e no longo prazo, à uma taxa de câmbio real que favoreceria a alocação de recursos para sectores tecnológicos mais intensivos.

PALAVRAS-CHAVE: Taxa de câmbio real; dilemas da política econômica; Brasil.
\end{abstract}

ABSTRACT: The aim of this paper is to discuss the trend of overvaluation of the Brazilian currency in the 2000s, presenting an econometric model to estimate the real exchange rate (RER) and which should be a reference level of the RER to guide long-term economic policy. In the econometric model, we consider long-term structural and short-term components, both of which may be responsible for explaining overvaluation trend of the Brazilian currency. Our econometric exercise confirms that the Brazilian currency had

\footnotetext{
* Banco Nacional de Desenvolvimento Social - BNDES e Universidade Federal Fluminense - UFF. e-mail: andrenassif27@gmail.com; Universidade Federal Fluminense - UFF e Conselho Nacional de Desenvolvimento Científico e Tecnológico-CNPq, e-mail: cfeijo@terra.com.br; Universidade Estadual de Maringá, e-mail: elianedearaujo@gmail.com. Submetido: 2/Setembro/2013; Aprovado: 17/Junho/2014.
} 
been persistently overvalued throughout almost all of the period under analysis, and we suggest that the long-term reference level of the real exchange rate was reached in 2004. In July 2014, the average nominal exchange rate should have been around 2.90 Brazilian reais per dollar (against an observed nominal rate of 2.22 Brazilian reais per dollar) to achieve the 2004 real reference level (average of the year). That is, according to our estimates, in July 2014 the Brazilian real was overvalued at 30.6 per cent in real terms relative to the reference level. Based on these findings we conclude the paper suggesting a mix of policy instruments that should have been used in order to reverse the overvaluation trend of the Brazilian real exchange rate, including a target for reaching a real exchange rate in the medium and the long-run which would favor resource allocation toward more technological intensive sectors.

KEYWORDS: Real exchange rate; economic policy dilemmas; Brazil.

JEL Classification: F30; F31; F39.

\section{INTRODUCTION}

One of the most controversial topics in recent economic literature concerns the determinants of the real exchange rate (RER). At least three alternative theories dispute arguments on how to establish the long-term RER: the more traditional theory of purchasing power parity (PPP), Williamson's (1983) alternative concept of the real exchange rate denoted by the fundamental equilibrium exchange rate (FEER), and Bresser-Pereira's concept of industrial equilibrium (2008) associated with the value of the exchange rate (2013). Nonetheless, in spite of the lack of theoretical consensus on how to determine the real exchange rate, empirical literature has shown that exchange rate overvaluation has negative effects on long-term economic growth (Razin and Collins, 1999; Dollar and Kraay, 2003; Prasad, Rajan and Subramanian, 2006; Gala (2008). Rodrik (2008) and Berg and Miao (2010) went further and showed empirical evidence that not only does overvaluation damage growth, but also that undervaluation benefits growth. Also, Williamson (2008) suggests that "the very best policy (in terms of maximizing growth) appears to be a small undervaluation" (p. 14, italics from the original) and concludes: "The evidence that overvaluation hurts development is now sufficiently strong to merit being reflected in policy, including delay to capital account liberalisation where it appears likely to threaten overvaluation" (p. 24).

According to Bresser-Pereira (2010), in developing countries the exchange rate presents a tendency to the cyclical and chronic overvaluation of the domestic currency in real terms. In fact, the Brazilian currency has shown a trend of real overvaluation since inflation was controlled in the mid-1990s. After 2004, this trend became stronger, and it has intensified since the aftermath of the 2008 international financial crisis, given the increase in capital flows from advanced economies into fast growing emerging economies. This trend has only been interrupted by either internal or external shocks. One of the main long lasting consequences of 
the long period of RER overvaluation has been early de-industrialization, ${ }^{1}$ and so a recurrent discussion in recent Brazilian economic literature is about how much the Brazilian currency has been overvalued. To shed some light on this topic, we develop an econometric model aiming at capturing the main explanatory variables of the real exchange rate in Brazil in the 2000s. Based on our econometric model we make an exercise to estimate the long-term reference level of the RER, assuming that this rate should float around the industrial equilibrium, what would mean "a small undervaluation" in relation to this latter level (the industrial equilibrium). With this hypothesis we come close to the literature that understands the long-term real exchange rate as a reference value which is able to reallocate the productive resources towards the sectors with the highest productivity or that makes profitable the business enterprises using world state of the technological art - what Bresserpereira calls the "industrial equilibrium". As a consequence, considering everything else equal, it would direct the economy towards technological and economic catching-up in the long run.

The remainder of the paper is organised as follows: the second section analyses the economic policy dilemmas that policy-makers in emerging economies have to face to avoid large real exchange rate overvaluation, under a floating exchange rate regime and free capital mobility. Third section critically discusses different theories of the determination of a real exchange rate. Fourth section presents the econometric estimate of the real long-term exchange rate in Brazil and a simple methodology to estimate the real long-term reference level of the RER in the 2000s. Fifth section draws the main conclusions and discusses some policy implications for Brazil.

\section{FLOATING EXCHANGE RATES REGIME AND FREE CAPITAL MOVE- MENTS: ECONOMIC POLICY DILEMMAS FOR EMERGING ECONOMIES}

\section{The "impossible trinity" and issues for emerging economies}

Recent international experience has shown that emerging countries, under flexible exchange rate regime and free capital mobility, actually intervene in their foreign exchange market in order to offset violent movements in the exchange rate. The success of such interventions in reducing exchange rate volatility or eliminating the misalignment (especially overvaluation) can be evaluated according to the policy space that monetary authorities have to implement counter-cyclical measures aimed at increasing output and employment while reducing external vulnerability. This space is reduced when short-term economic policy has to be used to restore the equilibrium of the balance of payments (Ocampo and Vos, 2006).

By discussing how some emerging Asian countries have tried to reduce high

\footnotetext{
${ }^{1}$ See, for example, Bresser-Pereira (2010), Bacha and Fishlow (2011), Nassif, Feijó and Araújo (2013), among others.
} 
volatility of their nominal exchange rate, Aizenman et al. (2010) argue that "a country may simultaneously choose any two, but not all, of the following three goals: monetary independence, exchange rate stability and financial integration. This argument, if valid, is supposed to constrain policy makers by forcing them to choose only two out of the three policy choices" (p. 2). In this sense, the authors offer a new version of the trilemma of economic policy that implies the choice of a mix of possibilities among different degrees of autonomy of monetary policy, foreign exchange intervention and capital mobility. Going further, they present sound econometric evidence that, since the Asian crisis of 1997, most Asian countries (except China), even without giving up a floating exchange rate regime and freedom of capital movements, have been very successful in by-passing the "impossible trinity" through an aggressive policy of accumulation of international reserves. In other words, rather than a dirty floating exchange rate regime like most Latin American countries (including Brazil), the Asian countries have, in practical terms, an administered floating exchange rate regime.

Since many emerging economies are characterised by some specificities such as non-convertible currencies, high volatility in the capital flows as well as recurring and persistent current account deficits, their operation of a floating exchange rate regime is often associated with high volatility in the nominal exchange rate, which leads to systematic interventions in the foreign exchange market. These interventions can be justified as a defensive measure to respond to the greater sensitivity that emerging economies have when it comes to external shocks and does not necessarily mean a "fear of floating", as Calvo and Reinhart (2002) argue. Consistent with the uncovered interest rate hypothesis, this would suggest a positive correlation between expectations of exchange rate depreciation and an increase in the domestic interest rate, in the assumption that the international interest rate remains unchanged.

However, particularly in the case of Brazil, the "fear-of-floating" argument seems to be misleading when it comes to explaining the large positive difference between domestic and external interest rates. As Silva and Vernengo (2009) argue, since the inflation rate target regime was introduced in Brazil in 1999, Brazil's Central Bank has managed the monetary policy in a very conservative way. ${ }^{2}$ In practical terms, its only goal has been to keep inflation rates low and very close to target. The authors conclude that, in the case of Brazil, rather than a "fear-offloating" behaviour, Brazil's Central Bank has presented a "fear-of-inflating" behaviour, meaning that this assumption would better explain the very high shortterm interest rate differential.

Given the considerations above, two stylised facts that narrow the policy space of economic authorities in emerging countries can be formulated.

\footnotetext{
${ }^{2}$ As an example of the conservative manner in which Brazil's Central Bank manages the monetary policy, after the outburst of the global financial crisis in September 2008, Brazil's basic interest rate (SELIC) was maintained at 13.75 per cent p.a. until January 2009, even taking into account the recessionary environment in Brazil. See Nassif (2010) for a comparative analysis between India and Brazil about this issue.
} 


\section{Unstable expectations in relation to the exchange rate contribute to exchange rate appreciation in emerging economie}

The uncovered interest rate parity $\left(i=i^{*}+e^{e}\right)$ determines that the domestic interest rate, $i$, is equal to the international rate, $i$, plus the expectation of exchange rate depreciation, $e^{e}$. This latter variable, in turn, is affected by many factors, especially by the country's risk premium. Thus, when the country's risk premium increases, the domestic currency is expected to depreciate $\left(e^{e}>0\right) .{ }^{3}$ This means, on the one hand, if high instability in the foreign exchange market is observed, the threat of depreciation puts pressure on the domestic interest rate to keep domestic assets attractive. This suggests a positive correlation between the short-term interest rate differential and the nominal (and real) exchange rate.

On the other hand, as soon as the foreign exchange market is stabilised again, an appreciation of the exchange rate is expected in response to the manipulation of the domestic interest rate by the central bank to avoid currency depreciation. The systematic increase in the short-term interest rate differential represents an additional incentive to sustain the exceeding flows of foreign short-term capital, especially those of a speculative nature. In practical terms, according to this stylised fact, since foreign investors tend to bet on the appreciation trend of currencies in emerging economies in the near future, the use of these currencies for carry-trade strategies implies that the uncovered interest rate parity is explicitly violated in the short term. That is to say, instead of reflecting expectations of depreciation, this fact reveals that the higher the interest rate differential, the greater the expectation that the domestic currency will continue to appreciate. So, in this case, the effect of an increase in the interest rate differential on exchange rate appreciation occurs with some time lag due to the attractiveness of large short-term capital inflows. This tendency will only be interrupted by sudden stops. ${ }^{4}$

\section{Excess of international liquidity pushes foreign capital towards open emerging economies and deteriorates gross public debt}

When international liquidity is plentiful and the inflow of foreign capital exceeds the necessity to finance balance of payments equilibrium, foreign reserves will increase. This increase, given the interest rates differential, implies financial

\footnotetext{
${ }^{3}$ The uncovered interest rate parity can also be expressed as $i=i^{*}+e^{e}+C R$, where CR is the country's risk premium (Rivera-Batiz and Rivera-Batiz, 1994). This expression makes it clearer that the final impact of an unexpected increase in the country's risk premium (e.g., following an external shock) is, through its effect on the expectations for domestic currency depreciation, to augment the domestic interest rate.

${ }^{4}$ On the use of the Brazilian currency (the real) in carry-trade strategies over the last few years, see Kaltenbrunner (2010).
} 
loss for the country, on one hand, and an increase in the gross public debt, on the other, that is equal to the part of the reserve that has been sterilised. This means policy-makers face a trade-off between purchasing international reserves to avoid a large real overvaluation of their currency and, since they have to sterilize the monetary impacts of that policy, absorbing this extra burden on gross public debt. The foreign reserve accumulation policy could also aim at building a net safety to prevent negative consequences in capital inflows in the long-term. Nonetheless, this policy has a clear negative impact on domestic fiscal policy. Also, it should be noted that the increase in the gross public debt has a negative effect on the country's risk premium. In this case, the assumption is that a higher gross public debt/GDP ratio increases expectations of exchange rate depreciation, which in turn puts pressure on the domestic interest rate.

\section{THEORETICAL DETERMINANTS OF THE REAL EXCHANGE RATE: STRUCTURAL AND SHORT-TERM VARIABLES}

At least two conventional theories compete to offer the most convincing hypothesis that explains both the determinants of the real exchange rate equilibrium in the long term and the causes of deviations of this trend in the very short term: the theories of purchasing power parity (PPP), and the fundamental equilibrium exchange rate (FEER). The PPP theory, which defines the real exchange rate as the relative price of a common basket of goods traded between two countries converted into the same numeraire, predicts that in an ideal world without any nominal price rigidity, transport costs, trade barriers or other short-term disturbance, that ratio should be equal to 1 . Since the hypothesis under the absolute version of the PPP theory is difficult to hold, the relative version of the PPP theory is more accepted, and it can be defined as (all variables in logarithms):

$$
R E R=e-\left(p-p^{*}\right)
$$

where $R E R$ is the real exchange rate;

$e$ is the nominal exchange rate (defined as the domestic currency price of foreign currency);

$p$ and $p^{*}$ are the domestic and foreign price levels, respectively.

This definition implies that a fall in both nominal and real exchange rates is an appreciation. In a study on the PPP theory, Taylor and Taylor (2004) stressed that empirical studies have shown a strong reversion of the real exchange rate equilibrium over time. Therefore, for an econometric study not to show a biased result, it is important to incorporate variables that can capture structural changes in the economy, such as the so-called Harrod-Balassa-Samuelson effect and the terms of trade.

The former refers to a tendency of a country that shows higher changes in productivity of tradable goods compared with non-tradable ones relative to the 
world economy to have higher price levels, that is to say, a real exchange rate appreciation. As Obstfeld and Rogoff (1996) concluded "the famous prediction of the Harrod-Balassa-Samuelson proposition is that price levels tend to rise (that is, the real exchange rate over time tends to appreciate) with country per capita income". This means that as soon as a country's per capita income increases, the demand for non-tradable goods (for instance, service activities) tends to overcome the demand for tradable goods and, therefore, to appreciate the domestic currency in real terms. ${ }^{5}$

The terms of trade (ToT) is another important variable associated with changes in the long-term structural behaviour of the real exchange rate. According to Baffes et al. (1999, p. 413) "an improvement in the terms of trade increases national income measured in imported goods; this exerts a pure spending effect that raises the demand for all goods and appreciates the real exchange rate" ${ }^{6}$ Edwards (1989) comments that most authors are used to establishing a negative relationship between the ToT and the RER. He also agrees that an improvement in the terms of trade, by augmenting the real income, results, in fact, in an increasing of the demand for non-tradable goods and, therefore, in a real exchange rate appreciation. However, Edwards (1989) emphasises that "a problem with this view is that the income effect is only part of the story [...] and both income and substitution effects, as well as intertemporal ramifications, should be analysed" (p.38). In other words, if the net income effect of an improvement of the ToT on the RER is positive, there will be a real exchange rate appreciation. This tends to be the immediate effect of the improvement in the ToT on the RER. However, after some time, the initial increase of the real income motivated by favourable ToT might be followed by replacement of the non-tradable goods for tradable ones. If this is the case, the substitution effect will prevail on the income effect and, given the increase of the relative prices of tradable goods, the impact on the RER will be depreciation. In other words, the expected effect of the ToT on the RER is ambiguous.

The FEER theory, on the other hand, was proposed by Williamson (1983) to connect either the medium or the long-term equilibrium real exchange rate (the so-called fundamental one) with the current economic policy. In simple terms, the FEER theory proposes that an equilibrium real exchange rate is one that assures the equilibrium of the current account in the long run. According to Williamson (1983), since policy-makers adopt economic policies compatible with the economic fundamentals, the FEER can be reached in the long run. It should be considered that both PPP and FEER theories were developed within the mainstream framework of the determination of the real exchange rate. In both approaches, the role of economic fundamentals is essential for explaining the movements of the real exchange rate in the long run. However, the forces that deviate the real exchange rate

\footnotetext{
${ }^{5}$ The main assumption of the Harrod-Balassa-Samuelson effect is that the richer a country is, the larger will be the income elasticity of demand for non-tradable goods compared with tradable goods.

${ }^{6}$ For a formal treatment, see Obstfeld and Rogoff (1996).
} 
from its "fundamental" long-term equilibrium are explained by either very shortterm price rigidity or monetary and real shocks, or any other market disturbances. Although an heterodox approach is not discussed in international economics textbooks, there has been some effort to propose an alternative theoretical framework in both Structuralist and Keynesian literature. In the first line of research, Bresser-Pereira (2010) proposes a Keynesian-structuralist approach to explain that in a world with floating exchange rate regimes and high freedom of capital movements, currencies of emerging economies have a persistent (cyclical and chronic) tendency to overvalue rather than undervalue.

Bresser-Pereira (2012, p. 352) classifies his approach as Keynesian-structuralist because this tendency to overvalue is driven by the following structural forces and by some usual policies: (i) the Dutch disease, which makes countries rich in natural resources to chronically overvalue their currencies in real terms; (ii) the attractive power with which countries scarce in capital absorb large amounts of short-term capital inflows; (iii) the policy of growth with foreign savings; (iv) the use of the exchange rate as a monetary anchor to control inflation; and (v) "exchange rate populism" - the decision of the politician to let the exchange rate overvalue to facilitate its re-election.

The author does not reject the existence of an equilibrium long-term real exchange rate, but, different from the mainstream approach where there is only one long-term equilibrium real exchange rate, Bresser-Pereira's thesis opens room for the existence of two long-term equilibrium real exchange rates: "an industrial equilibrium" exchange rate which could move the economy towards the international technological frontier and a trajectory of faster economic development, and, in the case of those countries which suffer from the Dutch disease, "a current equilibrium", that is, an exchange rate that tends to overvalue as it deviates the economy from the technological path consistent with economic development (Bresser-Pereira, 2010, chapter 4). As long as the long-term real exchange rate appreciation movement persists, both structural forces and usually adopted economic policies end up driving the economy to generate increasing current account deficits that will only be adjusted by a balance of payments crisis and a disruptive overshooting of the nominal and real exchange rate.

Another alternative view on the determination of the real exchange rate behaviour is offered by the Keynesian literature. Considering that there are no economic forces strong enough to guarantee that an economy will move towards equilibrium positions in the long term (the long term is the sum of a sequence of short-term events), the Keynesian theory rejects the distinction between long-term and short-term equilibrium exchange rates. ${ }^{7}$ Following this, even knowing that the Keynesian literature on the theme is very scarce, Kaltenbrunner (2008) argues that,

\footnotetext{
${ }^{7}$ This does not mean that the Keynesian approach rejects the existence of an reference real exchange rate, but that this indicator is essentially determined and influenced by economic policies.
} 
instead of market forces driven by fundamentals, real exchange rates are essentially explained by short-term capital flows.

As a matter of fact, Keynes (1923) had already recognised that short-term capital flows are one of the main transmission channels of interest rates differential between countries and exchange rate movements. However, rather than believing that this relationship would be based on the traditional uncovered interest rate parity, Keynes emphasised the role of the agents' forecast confidence (Harvey, 2006). As Harvey (2006, p.397) states,

the uncovered interest rate parity deviation is a forecast, and forecasts are never certain. In general, the more confidence agents have in their predictions, the more funds they are willing to commit in speculation. The more realistic way to incorporate this into this model would be to make capital flows (for a given uncovered interest rate parity deviation) go from a trickle to a strong flow as forecast confidence increased.

Similar to both Structuralist and Keynesian literature on the theme, we propose a model that rejects the long-term variables determined by "fundamental" forces as required by the PPP and FEER theories. In our econometric elaboration below, we consider two groups of variables: the first expresses long-term structural forces; and the second represents a set of variables directly or indirectly influenced by short-term economic policies. Differently from the conventional theoretical approaches, in the model proposed, not only the long-term trend of the real exchange rate, or as we call it, the long-term reference real exchange rate, but also the deviations of the actual real exchange rate from this reference level are jointly explained by long-term structural forces and short-term economic policies. ${ }^{8}$ Moreover, we reject the conventional wisdom of the existence of automatic forces driving the real exchange rate either towards a long-term equilibrium (such as the PPP approach) or even a real long-term reference level (as inherent in our framework). By supporting this argument, our model is expressed as:

$$
R E R_{t}=g_{t}\left(\text { structlt }_{t}\right)+m\left(s t_{t}\right)
$$

where $R E R_{t}$ is the actual real exchange rate and the variables that comprise the function $g()$ are interpreted as representing the long-term structural forces denoted by structlt $t_{t}$ which are better driven by both market competition and long-term economic policies, ${ }^{9}$ and the component $m$ ( ) incorporates the set of short-term variables $s t_{t}$ that are directly and indirectly influenced by short-term macroeconomic policies.

\footnotetext{
${ }^{8}$ See Razin (1996) and Razin and Collins (1999) for a conventional theoretical and empirical formulation.

${ }^{9}$ By long-term economic policies, we mean those government measures which are introduced with the objective of accelerating structural change and economic development, such as industrial and technological policies, trade policies and so on. In this sense, although it is hard to reject that the productivity change is one of the most important structural forces behind the long-term real exchange
} 
In fact, both structural and short-term economic policies may be responsible for not only driving the long-term real exchange rate towards its reference trend, but also (depending on the specificity of the structural force and the quality of the short-term economic policy) directing that indicator to a "suboptimal" level. The main policy implication of our model is that, like most Asian countries, policy-makers could (and should) target, at least partially, the real exchange rate in such a way that it could be driven towards a long-term reference level.

When the theoretical model is expressed in econometric specifications (fourth section), we cannot only capture the main determinants of the recent actual real overvaluation of the Brazilian currency, but also evaluate the policy space of shortterm economic policies, according to the explanatory power of the $m($ ) variables. Despite the fact that our model does not capture important characteristics related to the workings of foreign exchange markets, such as the dynamic changes and the forward-looking behaviour, its simplicity is attractive enough to provide a useful and comprehensive empirical implementation.

\section{REAL EXCHANGE RATE OVERVALUATION: EMPIRICAL EVIDENCE FOR BRAZIL IN THE 2000S}

The Brazilian currency has presented a trend towards overvaluation of its real exchange rate ever since inflation became controlled in the mid-1990s. The phase of the floating exchange rate regime (from January 1999 on), which was followed by the adoption of an inflation targeting regime, did not bring stability to the real exchange rate. After 2004, the trend towards real appreciation of the Brazilian currency, the real, became for the majority of the time a dominant pattern until the eruption of the international financial crisis in September 2008. After a sharp depreciation during the aftermath of the financial crisis, the appreciation trend of the Brazilian real has intensified again.

Figure 1 shows the evolution of the real exchange rate from February 1999 to February $2011 .{ }^{10}$ Considering the standard deviations of the real exchange rate, Figure 1 shows three distinct phases related to the trajectory of the RER. The first phase (standard deviation of 6.7) begins in the months immediately after the change in the Brazilian exchange rate regime. After a sharp depreciation of the real exchange rate at the end of 1998, the introduction of a floating exchange rate regime in early 1999 was followed by a relatively stable evolution in 2000 .

After this short period of relative stability, the second phase (standard devia-

rate, we must stress that the evolution of productivity is in itself strongly influenced by those kinds of the above mentioned long-term economic policies.

\footnotetext{
${ }^{10}$ Our empirical exercise considers data up to February 2011, because late in that semester the Brazilian government started to implement some capital control measures, which were abandoned in June 2013. We believe that leaving this period out of our estimations does not change our main conclusions and recommendations.
} 
Figure 1: Actual real effective exchange rate (monthly data) Brazil, February 1999-July 2014 2000 average real exchange rate $=100$

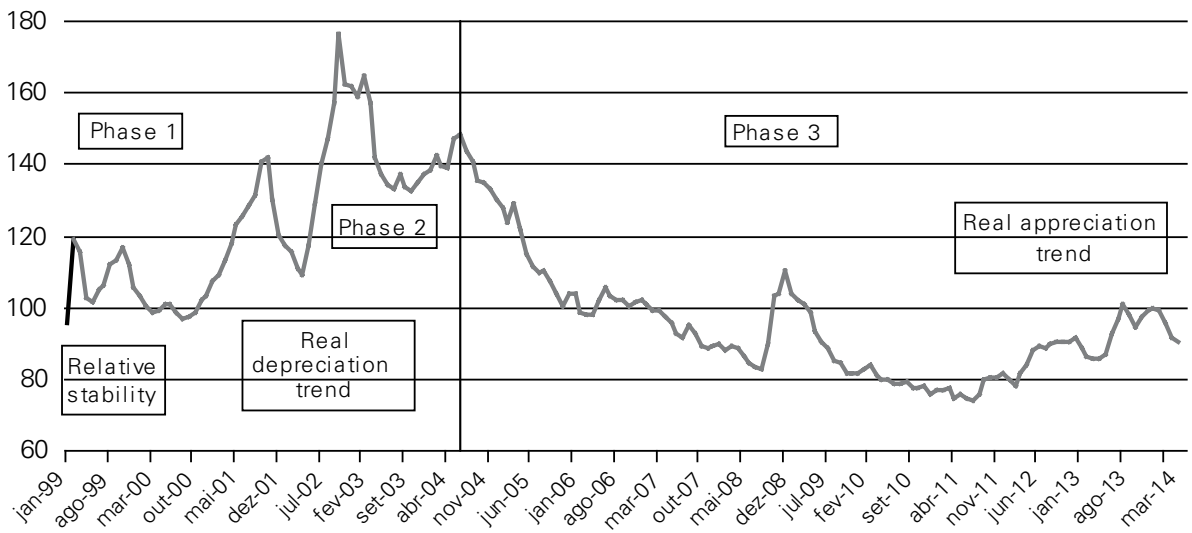

Source: Brazil's Central Bank.

tion of 16.8) was marked by the negative expectations of the presidential election of a candidate (Luiz Inácio Lula da Silva), who was at the time adversely evaluated by markets in Brazil. The Brazilian currency, in this second phase, showed a trend towards depreciation in real terms until mid-2004.

Throughout the third phase (standard deviation of 18.0), from June 2004 onwards, the real exchange rate showed an appreciation trend, except for the second half of 2008, when the international financial crisis triggered a brief movement of depreciation of the Brazilian currency. In this phase, the Brazilian economy was characterised by greater dynamism. In fact, the expansion of world trade, mainly after 2004, favoured the country's terms of trade, allowing the growth and real appreciation of its currency to occur simultaneously. ${ }^{11}$ In addition, in absence of capital controls, the excess inflow of external capital forced the Brazilian real to appreciate. This situation starts to change in 2012, due to changes in expectations about the recovery of the American economy.

\section{Econometric implementation}

Our theoretical framework presented in equation (2) will be translated into the following econometric specification (equation 3):

$$
\begin{aligned}
& \ln R E R_{t}=c_{0}+\alpha_{2} \ln Y_{t}+\alpha_{2} \ln T o T_{t}+\alpha_{3} \ln C A_{t}+\beta_{1}(\ln I D I F E R)_{t}+ \\
& +\beta_{2}(\ln I D I F E R)_{t-1}+\beta_{3} \ln S T K F_{t}+\beta_{4} \ln I R_{t}+\beta_{5} \ln C R_{t}+\varepsilon_{t}
\end{aligned}
$$

\footnotetext{
${ }^{11}$ Real GDP grew at $5.7 \%$ in $2004 ; 3.2 \%$ in $2005 ; 4.0 \%$ in $2006 ; 6.1 \%$ in 2007 , and $5.1 \%$ in 2008 .
} 
Following analogous procedures of empirical literature on the real exchange rate determination, we chose the most appropriate candidates to represent the variables associated with the structural changes in the real exchange rate in the long run (variables with the $\alpha$ coefficients on the right hand of equation (3)) and those directly or indirectly associated with the short-term policies (variables with the $\beta$ coefficients on the right side of equation (3)).

The variables of the model (see data source in Appendix 1) are specified in logarithms as follows: RER is the actual real effective exchange rate; $Y$ is the real GDP per capita in US dollar; ToT is the terms of trade; STKF is the net short-term capital flow expressed as a ratio of GDP; ${ }^{12} \mathrm{CA}$ is the current account balance expressed as a ratio of GDP; IDIFER is the differential of short-term domestic (SELIC basic rate) and international (US Fed Funds) interest rates; IDIFER $R_{t-1}$ is the previous variable lagged one period; $I R$ is the stock of Brazilian international reserves expressed as a ratio of GDP; $C R$ is Brazil's risk premium; $\varepsilon_{t}$ is a random error variable, which is also assumed to contribute to deviating the actual real exchange rate from its long-term trend level; and the subscript $t$ is the time reference (in our econometric modelling, it refers to one month). ${ }^{13}$

The variables chosen to represent the structural conditions to determine the real exchange rate are largely used in the empirical literature (Helmers, 1988; Edwards, 1988; Rodrik, 2008). And the short-term variables chosen are considered to be the most important for an open emerging economy according to the specific discussion in the second section ${ }^{14}$.

Following the basic econometric procedures, we investigated the potential non-stationarity of the variables and the potential endogeneity of the chosen explanatory variables. As for non-stationarity, we implemented the Augmented Dickey-Fuller (ADF) and the Phillips-Perron (PP) unit root tests. Except for the STKF, all other variables are non-stationary in levels (with a trend and intercept), but stationary in first differences, i.e., the series are I (1) at 5 per cent significance level. For this reason, and others which we will further discuss ahead, we removed the STKF variable from the model. Following Baffes et al. (1999), we consider that, since the econometric model is represented by a single equation, the most appropriate methodologies to estimate the determinants of the real exchange rate are the ordinary least squares (OLS) and the error correction model (ECM).

Before applying the cointegration test, it is important to stress that ECM mod-

\footnotetext{
${ }^{12}$ We computed the foreign investment for portfolio and other short-term foreign investments (mainly suppliers' credit and short-term loans) as short-term capital flows.

${ }^{13}$ Following Bogdanski, Tombini and Werlang (2000, p. 17), all variables with negative values (CA and $S T K F)$ were transformed adding a positive number in order to apply logarithms in the following procedures: $\mathrm{CA}=1+\mathrm{CA}$; and STKF $=2+\mathrm{STKF}$.

${ }^{14}$ These short-term variables can also be found dispersed throughout conventional empirical models. See, for instance, Meese and Rogoff (1983), Edwards (1988), Calvo, Leiderman and Reinhart (1993), among others.
} 
els are generally applied to non-stationary series which have a cointegration relationship. As supported by Campbell and Perron (1991), in reaching a cointegrated process between non-stationary series, the addition of a stationary variable in the ECM will not cause significant changes in the statistical robustness of the regression. However, when we included the stationary variable STKF in our econometric implementation, the model did not show a good fit. As we already discussed in the third section, since one of the main transmission channels from the interest rate differential to the real exchange rate is through the short-term capital flow, the removal of this variable does not damage the consistency of the model. Therefore, by removing the variable STKF from the econometric model, equation (3) is reexpressed by the following equation:

$$
\begin{aligned}
& \ln R E R_{t}=c_{0}+\alpha_{1} \ln Y_{t}+\alpha_{2} \ln T O T_{t}+\alpha_{3} \ln C A_{t}+\beta_{1}(\ln I D I F E R)_{t}+ \\
& +\beta_{2}(\ln I D I F E R)_{t-1}+\beta_{3} \ln I R_{t}+\beta_{4} \ln C R_{t}+\varepsilon_{t}
\end{aligned}
$$

Having established that the variables of equation (4) are non-stationary and possess the same order of integration I (1), we are able to apply the cointegration test so as to verify whether a linear combination of these variables is stationary. Following Engle and Granger (1987), if a unit root test reveals the residuals are stationary, i.e., I (0), we can conclude not only that all variables of our single equation are cointegrated in levels, but also that the estimated coefficients by ordinary least square (OLS) are consistent (Hamilton, 1994, p. 857; Greene, 1997, pp. 856857). The ADF and PP tests prove we can reject the null hypothesis of unit root in the residuals. So, according to Granger (1981) and Engle and Granger's (1987) procedure, since the residuals are stationary, the real exchange rate and its structural long-term and short-term determinants are cointegrated.

To deal with the potential endogeneity issues of our explanatory variables, we followed two methodologies. First, by applying Engle, Hendry and Richard's (1983) weak exogeneity test, the variables GDP per capita, international reserves and the terms of trade were revealed to be endogenous. A traditional way of addressing the potential for the endogeneity bias is to use instrumental variables that are able to correct the estimates through the use of exogenous variables, or instruments. Therefore, we also run the model in two stages least squares (2SLS).

Second, as Baffes et al. (1999) argue, even the relevant exogeneity tests proposed by Engle, Hendry and Richard (1983) might not be able to completely solve endogeneity problems when the marginal distribution of the explanatory variables shifts. Following this argument, in a model where more than one variable is endogenous, the Johansen (1988) cointegration procedure can be complementary for solving the endogeneity bias, since it treats all the variables in the estimation process as endogenous and tries to simultaneously determine the equilibrium relationship among them. Assuming that all the variables are I (1), the Johansen procedure, 
which considers all the I (1) variables as if they were endogenous and related to a vector-autoregressive structural model (VAR), uses the maximum likelihood estimation for the VAR model and derives a set of cointegration vectors. The number of cointegration vectors is determined by trace and eigenvalue tests. ${ }^{15}$ As Table 1 shows, the null hypothesis that there is a lack of cointegration relationship is rejected at 5 per cent significance level, both for trace and maximum eigenvalue test statistics. This means that there is strong evidence to support the existence of a cointegration vector which represents the long-term relationship among the variables of our model.

Table 1: Johansen Test of Cointegration Rank

\begin{tabular}{|l|llllll|}
\hline \multicolumn{3}{|c|}{ Trace statistics } & \multicolumn{4}{c|}{ Max-Eigen statistics } \\
\hline & Eigenvalues & $\begin{array}{c}\text { Critical } \\
\text { values }\end{array}$ & $\begin{array}{c}\text { Prob. } \\
5 \text { per cent }\end{array}$ & Eigenvalues & $\begin{array}{c}\text { Critical } \\
\text { values }\end{array}$ & $\begin{array}{c}\text { Prob. } \\
5 \text { per cent }\end{array}$ \\
\hline None & 177.5079 & 139.2753 & 0.0001 & 72.27859 & 49.58633 & 0.0001 \\
\hline At most 1 & 105.2293 & 107.3466 & 0.0683 & 40.66017 & 43.41977 & 0.0970 \\
\hline At most 2 & 64.56911 & 79.34145 & 0.3807 & 27.48926 & 37.16359 & 0.4124 \\
\hline
\end{tabular}

Note: 4 lags, with a trend and intercept.

Table 2 presents the results of our estimation in OLS, 2SLS and ECM according the econometric model specified in equation 4.

Table 2: Estimated model for Brazil.

Dependent variable: real exchange rate

\begin{tabular}{|c|c|c|c|c|}
\hline Variable & $\begin{array}{l}\text { Description of the } \\
\text { variables }\end{array}$ & $\begin{array}{c}\text { OLS } \\
\text { coefficient } \\
\text { (t-statistics } \\
\text { between brackets) }\end{array}$ & $\begin{array}{l}\text { 2SLS coefficient } \\
\text { (t-statistics } \\
\text { between brackets) }\end{array}$ & $\begin{array}{c}\text { ECM coefficient } \\
\text { (t-statistics } \\
\text { between brackets) }\end{array}$ \\
\hline$C$ & Constant & $\begin{array}{l}6.766^{* * *} \\
{[11.610]}\end{array}$ & $\begin{array}{c}2.659 * * \\
{[1.964]}\end{array}$ & $4.463 * * *$ \\
\hline $\operatorname{InGDP}$ & $\begin{array}{l}\text { Log of the real GDP } \\
\text { per capita }\end{array}$ & $\begin{array}{c}-0.356 * * * \\
{[-6.771]}\end{array}$ & $\begin{array}{l}-0.505^{* * *} \\
{[-11.588]}\end{array}$ & $\begin{array}{c}-0.505^{* * *} \\
{[-9.458]}\end{array}$ \\
\hline InTOT & $\begin{array}{l}\text { Log of the terms } \\
\text { of trade }\end{array}$ & $\begin{array}{l}-0.239^{*} \\
{[-1.744]}\end{array}$ & $\begin{array}{l}0.290^{*} \\
{[1.732]}\end{array}$ & $\begin{array}{l}0.568^{*} \\
{[1.582]}\end{array}$ \\
\hline $\operatorname{In} C A$ & $\begin{array}{l}\text { Log of the current } \\
\text { account balance/GDP }\end{array}$ & $\begin{array}{l}0.129^{* * *} \\
{[8.17]}\end{array}$ & $\begin{array}{l}0.227 * * * \\
{[13.988]}\end{array}$ & $\begin{array}{l}0.230 * * * \\
{[12.636]}\end{array}$ \\
\hline $\operatorname{Ln}(I D I F E R)$ & $\begin{array}{l}\text { Log of the } \\
\text { short-term interest } \\
\text { rate differential }\end{array}$ & $\begin{array}{l}0.121 * * * \\
{[3.266]}\end{array}$ & - & - \\
\hline
\end{tabular}

${ }^{15}$ See Enders (1995) and Hamilton (1994). 


\begin{tabular}{|c|c|c|c|c|}
\hline Ln(IDIFER) $)_{t-1}$ & $\begin{array}{c}\text { Log of the lagged } \\
\text { short-term interest } \\
\text { rate differential }\end{array}$ & $\begin{array}{c}-0.129^{* *} \\
{[-3.693]}\end{array}$ & $\begin{array}{c}-0.104^{* *} \\
{[-3.641]}\end{array}$ & $\begin{array}{c}-0.161^{* * *} \\
{[-4.236]}\end{array}$ \\
\hline \multirow{3}{*}{$\ln R$} & $\begin{array}{c}\text { Log of the stock } \\
\text { of international } \\
\text { reserves/GDP }\end{array}$ & $\begin{array}{c}0.115^{* * *} \\
{[4.088]}\end{array}$ & $\begin{array}{c}0.109^{* *} \\
{[2.538]}\end{array}$ & $\begin{array}{c}0.139^{* * *} \\
{[5.511]}\end{array}$ \\
\hline $\operatorname{InCR}$ & $\begin{array}{c}\text { Log of the Brazil's } \\
\text { risk premium }\end{array}$ & $\begin{array}{c}0.065^{* * *} \\
{[2.231]}\end{array}$ & $\begin{array}{c}0.194^{* * *} \\
{[3.453]}\end{array}$ & $\begin{array}{c}0.072^{* * *} \\
{[2.815]}\end{array}$ \\
\hline
\end{tabular}

Notes on OLS model: R-squared: 0.88745; Adjusted R-squared: 0.88169; Durbin-Watson: 1.633; F-statistics: 153.319; Prob (F-statistics): 0.0000; Number of observations: 145 after adjustments.

Notes on 2SLS model: R-squared: 0.8259; Adjusted R-squared: 0.8178; Durbin-Watson: 1.6106; F-statistics:

110.661; Prob (F-statistics): 0.0000; Number of observations: 145 after adjustments;

Instrument list: LOGTOT(-1) ; LOGIR(-1) ; LOGIDIFER(-2) ; LOGGDP(-1) ; LOGCR(-1)

LOGCA(-1); LOGTOT(-8) LOGTOT(-9)

Notes on ECM model: 4 lags; Number of observations: 141 after adjustments.

Note: ** Significant at 1 percent level; ** Significant at 5 percent level; * Significant at 10 percent level.

Among the structural variables, all the three models revealed that the largest estimated coefficients were the GDP per capita and the terms of trade, respectively. ${ }^{16}$ The real GDP per capita, with a negative sign, supports the Harrod-BalassaSamuelson effect. However, the high coefficient estimated for this variable should be cautiously analysed. In fact, far from reflecting an expressive growth in either labour productivity or even total factor productivity (TFP) in Brazil, the growth of the real GDP per capita in the last decade (especially in the last few years) resulted from a set of well succeeded social policies which led to a significant improvement in income distribution. ${ }^{17}$ So, rather than expressing an increase in productivity, which has been stagnant in the 2000s, it expresses an improvement in the income distribution due to a set of social policies (e.g., the Family Assistance Program Bolsa Familia, among others).

In the OLS model the terms of trade ToT presented a negative sign, so an improvement of 10 per cent in the terms of trade appreciates the long-term trend of the real exchange rate by 2.39 per cent. However, when this variable is considered with lags, both in the 2SLS and ECM models, the medium-term impact is to depreciate the Brazilian currency. So this seems to confirm the ambiguous effects of the terms of trade on the real exchange rate, as supported by Edwards (1989) and already discussed in the third section.

The expected sign of the current account balance to GDP ratio $(C A)$ is also ambiguous. On the one hand, ceteris paribus, the more a country shows current account surplus, the more appreciated its currency will be in real terms. On the other hand, we could also argue that large current account surpluses, by being

\footnotetext{
${ }^{16}$ Among the structural variables, the terms of trade showed the largest estimated coefficient in the ECM model.

${ }^{17}$ If we take into account the total factor productivity (TFP), an indicator of aggregate efficiency, the annual average growth was less than 0.5 per cent between 2002 and 2009 (against 4 per cent in China and 2.6 per cent in India (see The Economist, November 18, 2009)).
} 
associated with large domestic savings in the long run, tend to increase the incentives of the demand for foreign exchange for purchasing external assets and, furthermore, to depreciate the long-term real exchange rate. Then, if this is the case, we could expect a positive sign for the current account to GDP ratio. In fact, although the estimated sign for the Brazilian case has been positive, it is necessary to stress that, on average, Brazil presented large net capital inflows during the period under analysis. This suggests that Brazil's current account balance seems to be strongly associated with a depreciated currency in real terms, though we cannot draw any conclusion on the causality relationship between the former variable and the Brazilian real exchange rate behaviour.

Among the short-term economic policy variables, the short-term interest rate differential and the international reserves showed the largest estimated coefficient. Though the country-risk premium has presented a high estimated coefficient in the 2SLS model, it presented low estimated ones in both OLS and ECM models. Nonetheless, the estimated positive coefficient of the country-risk premium implies that a higher coefficient of this variable is associated with an "undervalued currency" in real terms, as suggested by the theoretical literature.

As supported by the analysis in the second section, the very short-term impact of the interest rate differential might reflect a "fear of inflating", given the context of the current inflation targeting regime in Brazil. So, we should expect a positive sign in the interest rate differential, as shown in the OLS model. At the same time, the increase in the country's risk premium is reinforced every time the Brazilian economy faces either an internal or external shock, which, by indicating or eventually provoking a sudden stop in capital flows, compels Brazil's Central Bank to maintain the short-term interest rate differential at a high level. On the other hand, the incorporation of the lagged short-term interest rate differential into the econometric model is based on the assumption that the short-term interest rate differential impacts the real exchange rate with some time lag through its effects on net short-term capital inflows.

The stock of international reserves as a ratio of GDP is, along with the interest rate differential, one of the largest to correlate with the real exchange rate. It is necessary to stress, though, that the relationship between this variable and the real exchange rate is ambiguous. On the one hand, by reducing the country's risk premium, the larger the stock of international reserves, the lower the expectation for real exchange rate depreciation, considering everything else equal. If this is the case, the expected sign should be negative. On the other hand, a larger stock of international reserves also reflects the central bank's strategy of accumulating foreign reserves as an attempt to either target a long-term reference real exchange rate (like most Asian countries) or avoid a large real exchange rate overvaluation (a defensive strategy). In both cases, the expected sign should be positive, although the defensive strategy seems to be the case of Brazil in the period under analysis. 


\section{The long-term trend and the estimation}

of the long-term real reference exchange rate

Our aim in this section is to take the regressors of the econometric model to estimate the long-term trend of the real exchange rate $(R \hat{E} R)$. This result is then compared with the actual real exchange rate $R E R$ to construct an index that allows us to evaluate the trend of real exchange rate overvaluation in Brazil. As suggested by Edwards (1989) and Alberola (2003), this paper uses the Hodrick-Prescott (HP) filter technique to estimate (RERR). Figure 2 jointly shows the actual (RER) and long-term estimated real exchange rates $R \hat{E} R$ (this latter by OLS, 2SLS and ECM models). As Figure 2 reveals, the episodes that produced strong and damaging depreciations happened exclusively in response to either internal or external shocks (such as in early 1999, due to the speculative attack which forced the adoption of a floating exchange rate regime in Brazil; in the first semester of 2001 in virtue of the severe electric energy crisis - the apagão crisis; in the second semester of 2002, due to the negative expectations of the upcoming presidential elections; and in the aftermath of the September 2008 financial crisis).

Figure 2: Actual and long-term estimated real exchange rates in Brazil:

February 1999-February 2011 (in logarithms)

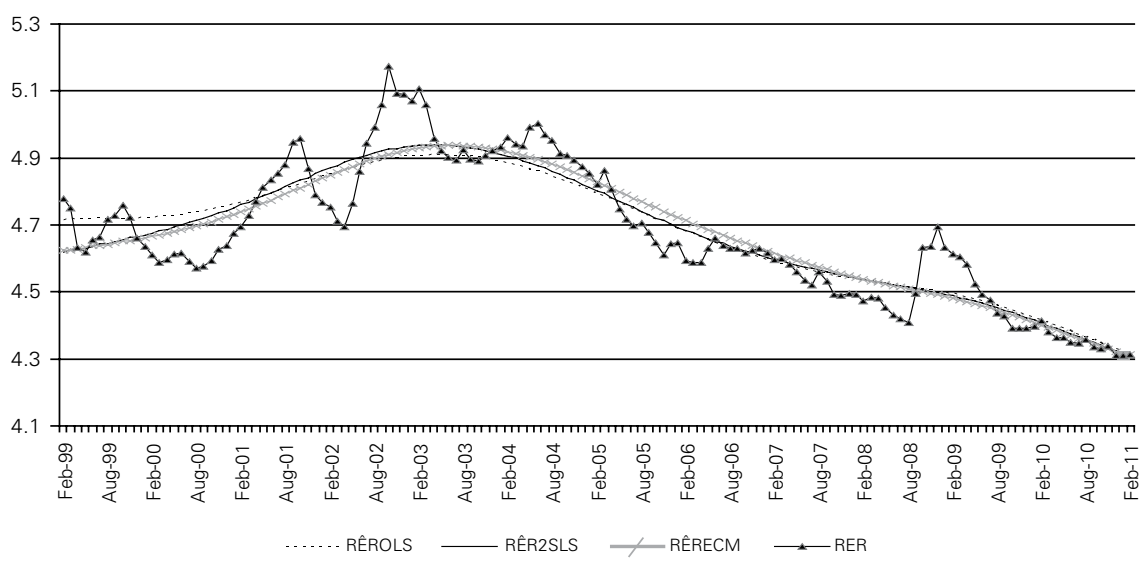

Source: Estimated by authors according to the described methodology.

Figure 2 also highlights three additional points: first, since the general trend of both actual and long-term estimated real exchange rate is similar, the results support the robustness of our models to capture the long-term trend of the real exchange rate in Brazil throughout the period; second, the very close results of the estimations by OLS, 2SLS and ECM demonstrate that both the explanatory variables and the methodologies chosen to estimate the determinants of the long-term trend of the Brazilian real exchange rate overvaluation are appropriate; and third, there has been a persistent tendency of the long-term real exchange rate in Brazil to overvalue and be directed towards a "suboptimal" level. This overvaluation 
trend could have only been considered "healthy" if it was explained by a significant increase in either Brazilian labour productivity or TFP, which, as already mentioned, has not been the case throughout the period under analysis.

Given these specificities, one could wonder which should be the level of a longterm reference real exchange rate, that is, the one that would favor resource allocation toward more technological intensive sectors. Our attempt to estimate this level is, at first, to identify in the 2000s a reference period, that is to say, a moment in which the economy had shown sound macroeconomic indicators (on average) and, at the same time, a small estimated real undervaluation. Next, we compare the evolution of the actual real exchange rate (RER) and the long-term estimated real exchange rate (RER) in the three models.

Figure 3 shows that the actual real exchange rate floated around the industrial equilibrium or kept a small undervaluation related to its long-term estimated trend only in 1999, 2001 and between mid-2003 and mid-2005. The period from mid-2003 to mid-2005 was the only one during which the Brazilian economy combined sound macroeconomic indicators with a small estimated real exchange rate undervaluation. ${ }^{18}$ So, taking this period as reference, the average of the estimated index of the long-term real exchange rate was 129.55 (OLS: 126.47; 2SLS: 129.53; and ECM: 132.66). This level of reference of the long-term real exchange rate offer us a measure of the Brazilian currency overvaluation. Take, for instance, April 2011. Comparing the reference level (129.55) with the index of the real exchange rate observed in April 2011 we conclude that in April 2011 the Brazilian actual real exchange rate showed a real overvaluation of around 80 per cent in relation to its long-term reference level: ${ }^{19}$ that is to say, in April 2011, the average nominal exchange rate should have been around 2.90 Brazilian reais per dollar (against an observed nominal rate of 1.59 Brazilian reais per dollar) to achieve the 2004 reference level (average of the year). Finally, it is important to stress that our econometric methodology has some limitations. Perhaps, the most important is that, since capitalist economies are characterised by uncertainty and non-ergodicity, structural change can happen in such way that even if the economy has reached the reference level of the real exchange rate in one period in the past, that level can change over time. This means that our exercise cannot be extrapolated naturally to the future. In other words, in order to know what the reference level would be for the Brazilian real exchange rate in 2020, similar econometric exercise should be done again.

\footnotetext{
${ }^{18}$ We investigated ten macroeconomic indicators, such as GDP growth, consumer inflation, international reserves/GDP, current account balance/GDP, external debt/GDP, among others. All data from Brazil's Central Bank.

${ }^{19}$ Our estimates were firstly published in 2011 (see Nassif, Feijó and Araújo, 2011). In July 2014, after the continuous appreciation of the US dollar throughout 2013 and 2014, the Brazilian real was rated at 2.22 Brazilian reais per dollar. This means an overvaluation of the Brazilian currency of 30.6 per cent relative to the US dollar in real terms.
} 
Figure 3: Level of undervaluation or overvaluation of the actual real exchange rate related to the long-term estimated trend February 1999-February 2011

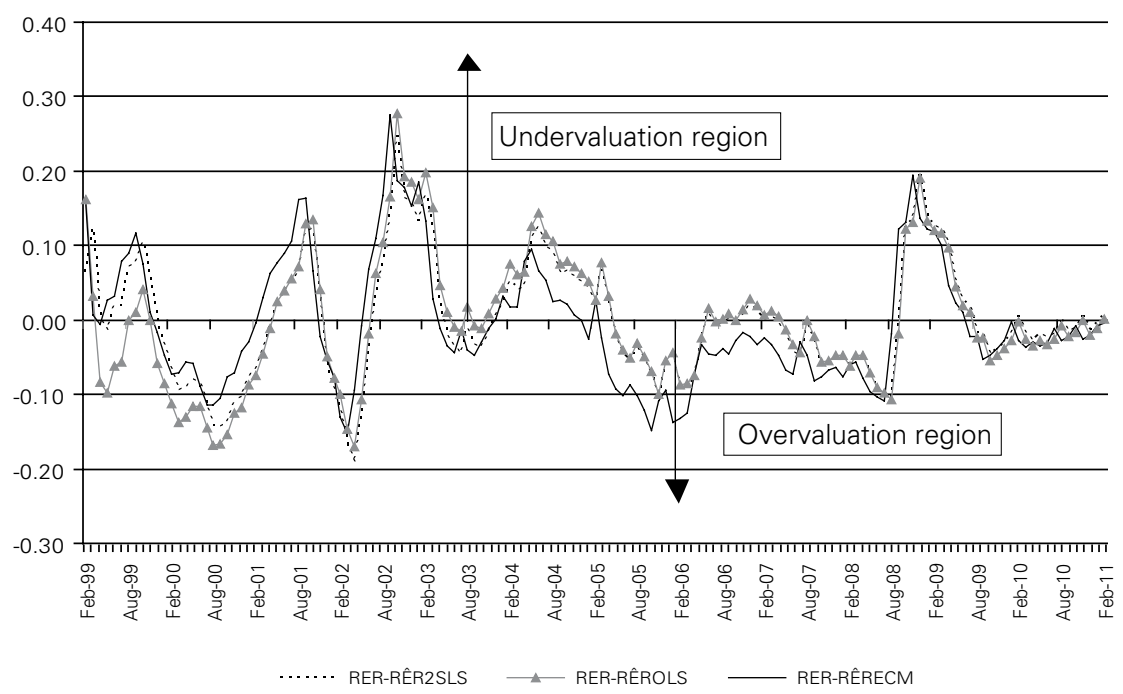

Note: Undervaluation and overvaluation are calculated by the difference between the actual RER and the estimated long-term trend of the RER (RÊR) If this result is above zero, there is an undervaluation; if it is less than zero, there is an overvaluation.

Source: Estimated by authors according to the described methodology.

\section{CONCLUDING REMARKS AND ECONOMIC POLICY IMPLICATIONS}

In the recent experience of a floating exchange rate regime with relatively high capital movements in Brazil, policy-makers clearly face the challenges imposed by the trilemma of economic policy. So, finding out how to overcome the "impossible trinity", that is to say, how to choose two out of three competing policy goals monetary independence, exchange rate stability and high external financial integration - is still on the agenda of the Brazilian economic policy. In practical terms, it is not an exaggeration to say that Brazilian policy-makers, by having pursued monetary independence to assure price stability and high external financial integration as priority goals for economic policy in the last decade, have tolerated the high volatility and a large overvaluation trend of the real exchange rate. This trend is supported by our econometric equation that allowed us to estimate the real exchange rate throughout the 2000s, combining structural long-term variables and short-term economic policy variables.

Aizenman et al. (2010) showed econometric evidence that, since the $1997 \mathrm{fi}$ nancial crisis, Asian emerging market economies have been successful in dampening the negative impacts of large short-term net capital flows on the real exchange rate overvaluation through massive accumulation of international reserves. The authors suggest that "policy makers in a more open economy would prefer to pursue greater exchange rate stability" (p. ii). Nevertheless, in the case of Brazil, since our 
econometric results reveal that the actual real exchange rate has been significantly overvalued ${ }^{20}$ it is not recommended to introduce policy instruments too quickly to correct this high level of overvaluation. Since Brazilian policy makers are facing difficulty in their economic policy choices, the most appropriate macroeconomic policy is to implement a mix of policy instruments which should prevent the strong trend of overvaluation while preserving price stability. This challenge demands policy makers to assume a target for the reference level of the real exchange rate in the medium and the long-run. This goal is more or less in line with the UNCTAD's recent proposal of using the "real effective exchange rate (REER) as a simple and viable system for averting exchange rate misalignment and the prevention of carry trade based on currencies" (UNCTAD, 2011, p. 1). ${ }^{21}$

First of all, the policy space for avoiding the real exchange overvaluation through accumulation of international reserves is much more limited in Brazil than in Asian emerging market economies, because, by virtue of maintaining high Brazilian interest rates under the inflation target regime, this strategy has adverse effects on the gross public debt. However, our econometric exercise showed that the estimated coefficient of the stock of international reserves was statistically significant and presented a positive sign. This means that, even taking into account that this strategy can increase the gross public debt, this mechanism has been somewhat influential in mitigating the real exchange rate's trend of overvaluation and has contributed to offsetting high volatility. So, as long as policy-makers are able to manage the impact of interventions on the spot and forward foreign exchange markets on the growth of gross public debt, Brazilian monetary authorities should continue to pursue the strategy of accumulating international reserves.

Secondly, the terms of trade figured in the OLS model as one of the main structural factors responsible for the overvaluation trend of the Brazilian currency in the long run. Since this result is explained in turn by the recent behaviour of the high relative prices of agricultural products and manufactured commodities in global markets, the basic policy implication is that Brazilian authorities should neutralize the threat of the Dutch disease by implementing industrial and technological policies with the goal of reallocating resources and promoting structural change towards sectors that are technologically more sophisticated. In this sense, a strong ally of industrial and technological policies is the commitment to keep the real exchange rate slightly undervalued in real terms in the long run, say around 5 per cent.

Thirdly, since the short-term interest rate differential in Brazil has figured as

\footnotetext{
${ }^{20}$ According to the UNCTAD's proposal, the most appropriate observed indicator for estimating the misalignment of the REER is the unit labour cost (that is, the premium of nominal wages over total productivity of the economy) rather than consumer price indices. So, policy-makers should target the "equilibrium" real exchange rate by realigning nominal exchange rates to the domestic cost level. For details, see UNCTAD, 2011,

${ }^{21}$ The total investment of the central government as a proportion of Brazilian GDP was only 1.3 per cent in 2010, a very low rate for a country with poor physical and social infrastructure.
} 
one of the highest in the world, Brazilian monetary authorities should enlarge the policy space for bringing the domestic interest rates to levels closer to international standards, and so contributing to the undervaluation of the domestic currency. One could argue that this possibility is very limited in Brazil, as the main concern of the inflation target regime is price stability. However, this goal is not incompatible with the effort to reduce domestic interest rates. There are academic studies suggesting that the design of the inflation target regime in Brazil could be modified in order to give monetary authorities more room to reduce the SELIC basic interest rate. One of the recommendations is to manage the inflation target through a calendar year of 18 months (see, among others, Oreiro et al., 2009; and Squeff et al., 2009).

Fourthly, we also agree that fiscal policy responsibility, through which the growth of current government expenditures in real terms must be lower than the increase of the real GDP, could contribute not only to supporting a drop in Brazilian policy interest rates, but also to augmenting the public investment to GDP ratio in Brazil. ${ }^{22}$ It is necessary to remark, however, that, without some change in the conservative way with which the Brazilian inflation targeting regime has been managed since it had been introduced in 1999, fiscal policy responsibility per se is not sufficient for reducing high interest rates in Brazil. It is important to recognise that there have been changes in the way Brazil's Central Bank manipulates the monetary policy under the inflation target regime. After September 2008 Brazil's Central Bank has been adding other instruments and strategies, besides the management of the SELIC rate, such as compulsory reserve requirements, capital requirements to strengthen bank balance sheets and the apparent and undeclared acknowledgment of the challenges and high costs associated with the reaching the current inflation target in a single calendar year. Even so, inflation is becoming persistent and the Brazilian economy has shown little growth in 2011 and 2012.

Finally, Brazilian policy-makers should not discard the use of more effective mechanisms for capital control as suitable mechanisms for economic policy. Taking into account that international interest rates might be maintained at a low level in the near future, due to the stagnant environment in the world economy, the high short-term interest rate differential will continue to contribute to the appreciation of the Brazilian currency in real terms, and keep it far from its reference long term value. Even conservative voices have upheld that some sort of protection against speculative short-term capital inflows should be established by emerging economies to avoid exchange rate overvaluation. A recent International Monetary Fund Staff Position Note (see Ostry et al., 2010, among others) concluded that "capital controls are a legitimate part of the toolkit to manage capital inflows in certain circumstances" (p. 15). ${ }^{23}$ In fact, although the overvaluation trend of the Brazilian

\footnotetext{
22 The total investment of the central government as a proportion of Brazilian GDP was only 1.3 per cent in 2010, a very low rate for a country with poor physical and social infrastructure.

${ }^{23}$ For a detailed country study on short and medium run capital control experiences, see BIS, 2008.
} 
currency had been continuing since 2004, as this trend deepened in 2010, a set of measures of capital control - until then a forbidden topic among Brazilian economic policy-makers - have been introduced up to July 2011, most of them involving financial tax on short-term capital inflows directed to bond purchases and transactions tax on future markets (especially on the currency derivatives market). Part of these measures start to be removed in June 2013, due to difficulties in controling inflation this year.

The main issue is that these governmental measures (including the mix of the above suggested macroeconomic policies) should have been implemented in mid2009 , when the real exchange rate began to show a sustained trend of appreciation again - once having overcome the strong depreciation that follow the September 2008 financial crisis - , and not in ad hoc small doses as has ocurred from early 2010 on. Currently, as the current account deficits have been increasing dramatically from 2009 to 2013, the imposition of radical measures of capital control (e.g., quantitative constraints against capital inflows) is much harder to implement, given the need of large amounts of extenal savings to finance the current account deficits. In other words, it is much more difficult to find an organized exit from a potential exchange rate crisis when the country's external financial vulnerability has dramatically increased.

To conclude, there are at least two reasons the strong real exchange overvaluation should have been avoided: first, as has been strongly supported by the empirical literature, a large and continued overvaluation in the short term can damage long-term economic growth; and second, as stressed by Dornbusch (1988) a long time ago, although a floating exchange regime can provide for the correction of overvaluation in the medium term, the aftermath of a correction by free-market forces is far from being a "first best" solution since it can lead to severe macroeconomic instability and requires high adjustment costs: balance-of-payments crises, inflation, high interest rates and real GDP reduction.

\section{REFERENCES}

Aguirre, Alvaro, and Calderón, Cesar (2006). "The Effects of Real Exchange Rate Misalignments on Economic Growth”. Santiago de Chile: Central Bank of Chile, Economic Research Division.

Aizenman, Joshua, Chinn, Menzie D., and Ito, Hiro (2010). "Surfing the Waves of Globalization: Asia and Financial Globalization in the Context of the Trilemma". La Follette Working Papers Series 2010-009. Robert M. La Follette School of Public Affairs. The University of Wisconsin-Madison.

Alberola, E. (2003). "Misalignment, Liabilities Dollarization and Exchange Rate Adjustment in Latin America". Banco de Espanha Working Papers 309, Banco de Espanha.

Bacha, Edmar and Fishlow, Albert (2011). 'The recent commodity price boom and Latin American Growth: More than new bottles for an old wine? In: J.A. Ocampo and J. Ros (orgs). The Oxford Handbook of Latin American Economics. Oxford: Oxford University Press.

Baffes, John, Elbadawi, Ibrahim and O'Connel, Stephen A. (1999). "Single-Equation Estimation of the Equilibrium Real Exchange Rate” in Hinkle, L.E. and P.J. Montiel, P.J. Exchange Rate Misalignment: Concepts and Measurement for Developing Countries. World Bank Research Publication, Oxford University Press. 
Berg, Andrew and Miao, Yanliang (2010). “The Real Exchange Rate and Growth Revisited: The Washington Consensus Strikes Back?” IMF Working Paper 10/58. Washington: International Monetary Fund.

BIS (2008). "Financial Globalization and Emerging Market Capital Flows”. BIS Papers 44. Basel (Switzerland): Bank for International Settlements, December.

Bogdanski, Joel, Tombini, Alexandre A. and Werlang, Sérgio R. C. (2000). "Implementing Inflation Targeting in Brazil”. Working Papers Series 1. Brasilia: Banco Central do Brasil (available at http://www.bcb.gov.br).

Bresser-Pereira, Luiz Carlos (2008) "Dutch disease and its neutralization: a Ricardian approach", Brazilian Journal of Political Economy 28 (1) January: 47-71.

Bresser-Pereira, Luiz Carlos (2010). Globalization and competition. why some emerging countries succeed while others fall behind. Cambridge: Cambridge University Press.

Bresser-Pereira, Luiz Carlos (2012) "Structuralist macroeconomics and new developmentalism", Brazilian Journal of Political Economy 32 (3) July 2012: 347-366.

Bresser-Pereira, Luiz Carlos (2013) "The value of the exchange rate and the Dutch disease”, Brazilian Journal of Political Economy 33(3) julho 2013: 371-387.

Calvo, Guillermo, and Reinhart, Carmen (2002)."Fear of Floating”. Quarterly Journal of Economics, 117(2), pp. 379-408.

Calvo, Guillermo, Leiderman, Leonardo and Reinhart, Carmen (1993). "Capital Inflows and Real Exchange Rate Appreciation in Latin America. The Role of External Factors”. IMF Staff Papers, Vol. 40, no. 1. Washington, DC: International Monetary Fund.

Campbell, J.Y. and Perron P. (1991). "Pitfalls and Opportunities: What Macroeconomists Should Know About Unit Roots and Cointegration”. NBER Macroeconomics Annual, Cambridge, MA: MIT Press.

Dollar, David and Kraay, Aart (2003). "Institutions, Trade and Growth”. Journal of Monetary Economics. Elsevier, vol. 50, $\mathrm{n}^{\circ}$ 1:133-162. January.

Dornbusch, Rudiger (1988). Overvalution and Trade Balance, in R. Dornbusch and F.Leslie C. H. Helmers (eds). The Open Economy: Tools for Policymakers in Developing Countries. Oxford University Press.

Edwards, Sebastian (1988). "Real and Monetary Determinants of Real Exchange Rate Behavior: Theory and Evidence from Developing Countries". UCLA Working Paper Number 506. Los Angeles: University of California, Los Angeles. September.

Edwards, Sebastian (1989). Real Exchange rates, Devaluation, and Adjustment: Exchange Rate Policy in Developing Countries. Cambridge, MA: MIT Press, 1989.

Enders, W. (1995). Applied econometric time series. John Wiley \& Sons.

Engle, R. F., Hendry, D. F. and Richard, J. F. (1983). "Exogeneity”. Econometrica. Vol. 51: 277-304.

Engel, R.F. and Granger, C.W.J. (1987). "Co-integration and error correction: representation, estimation, and testing," Econometrica, 55, pp. 251-276.

Gala, Paulo (2008). "Real Exchange Rate Levels and Economic Development: Theoretical Analysis and Econometric Evidence”. Cambridge Journal of Economics 32:273-288

Granger, C. W. J. (1981): "Some Properties of Time Series Data and Their Use in Econometric Model Specification,” Journal of Econometrics, 121-130.

Greene, Willian H. (1997). Econometric Analysis. New Jersey: Prentice-Hall.

Hamilton, J. D. (1994). Time series analysis. Princeton University Press.

Harvey, John T. (2006). “Modeling Interest Rate Parity: A System Dynamics Approach”. Journal of Economic Issues, June: 395-403.

Hausmann, Ricardo, Panizza, U. and Stein, E. (2000). "Why do countries float the way they float?". Interamerican Development Bank Working Paper no. 418.

Helmers, F. Leslie C.H. (1988). "The Real Exchange Rate”. In Dornbusch, R. and F. Leslie C. H. Helmers (eds). The Open Economy: Tools for Policymakers in Developing Countries. Oxford: Oxford University Press. 
Johansen, S. (1988). Statistical Analysis of Cointegrating Vectors. Journal of Economic Dynamics and Control, 12: 231-254.

Kaltenbrunner, Annina (2008). “A Post-Keynesian Look at the Exchange Rate Determination in Emerging Markets and its Policy Implications: The Case of Brazil". Paper presented at the Research Network Macroeconomics and Macroeconomic Policies, 12th Conference on "Macroeconomic Policies on Shaky Foundations - Whither Mainstream Economics" 31 October-1 November, Berlin.

Kaltenbrunner, Annina (2010). "International Financialization and Depreciation: The Brazilian Real in the International Financial Crisis”. Competition and Change, Vol. 14 (3-4), December: 296-323.

Keynes, John M. (1923). “A Tract on Monetary Reform”. The Collected Writings of John Maynard Keynes IV. London: Macmillan, 1973

Meese, Richard, and Rogoff, Kenneth (1983). "Empirical Exchange Rate Models of the 1970s: Do They Fit Out of Sample?”. Journal of International Economics 14: 3-24.

Nassif, André (2010). "Brazil and India in the Global Economic Crisis: Immediate Impacts and Economic Policy Responses" In: Dullien, S., D. Kotte, A. Márquez and J. Priewe (eds). The Financial and Economic Crisis of 2008-2009 and Developing Countries. Jointly published by the United Nations Conference on Trade and Development and Hochschule für Technik und Wirtschaft Berlin.

Nassif, André, Feijo, Carmem and Araujo, Eliane (2011). "The Long-term "Optimal” Real Exchange Rate and the Currency Overvaluation Trend in Open Emerging Economies: the Case of Brazil". UNCTAD Discussion Papers n ${ }^{\circ}$ 206. Geneva: United Nations Conference on Trade and Development (UNCTAD). December (available at http://unctad.org/en/pages/publications/Discussion-Papers-(Series).aspx).

Nassif, André, FEIJO, Carmem and ARAUJO, Eliane. (2013). "Structural change and economic development: is Brazil catching up or falling behind?”, UNCTAD Discussion Paper n ${ }^{\circ} 211$. Geneva: United Nations Conference on Trade and Development (UNCTAD). October (available at http:// unctad.org/en/pages/publications/Discussion-Papers-(Series).aspx).

Ocampo, Jose Antonio and Vos, Rob. (2006). "Policy Space and the Changing Paradigm in Conducting Macroeconomic Policies in Developing Countries” In Bank for International Settlements (ed.) New financing trends in Latin America: a bumpy road towards stability: 28-45, Also available at Bank for International Settlements, BIS papers chapters, number 36-03: http://ideas.repec.org/s/ bis/bisbpc.html

Oreiro, José Luis, Passos, Marcelo, Lemos, Breno and Padilha, Rodrigo (2009). "Metas de Inflação, Independência do Banco Central e a Governança da Política Monetária no Brasil: Análise e Proposta de Mudança” In: Luiz F. de Paula and Rogério Sobreira (org.) (2009). Política Monetária, Bancos Centrais e Metas de Inflação: Teoria e Experiência Brasileira. Rio de Janeiro: Ed. FGV.

Peel, D. and Taylor, Mark (2002). "Uncovered Interest Rate in the Interwar Period and the Keynes-Einzig Conjecture”. Journal of Money, Credit and Banking, Vol. 34 (1), February: 51-75.

Prasad, Eswar, Raghuram Rajan, and Arvind Subramaniam (2006). "Foreign Capital and Economic Growth”. Washington: IMF Research Department.

Razin, Ofair (1996). Real Exchange Rate Misalignments. Ph.D. Dissertation. Department of Economics, Georgetown University.

Razin, Ofair and Collins, Suzan M. (1999). "Real Exchange Rate Misalignments and Growth". In: Razin, A. and Sadka, E. (ed.). The Economics of Globalization: Policy Perspectives from Public Economics. Cambridge: Cambridge University Press.

Rivera-Batiz, Francisco L. and Rivera-Batiz, Luis A. (1994). International Finance and Open Economy Macroeconomics. 2nd Edition. New Jersey: Prentice Hall Publishers.

Rodrik, Dani (2008). “The Real Exchange Rate and Economic Growth”. Brookings Papers on Economic Activity, 2:365-412.

Silva, Carlos Eduardo S. and Vernengo, Matias (2009). "The decline of the exchange rate pass-through in Brazil: explaining the fear of floating”. International Journal of Political Economy, 37(4), pp. 64-79. 
Squeff, Gabriel C., Oreiro, J. L. and Paula, L. F. (2009). "Flexibilização do Regime de Metas de Inflação em Países Emergentes: Uma Abordagem Pós-Keynesiana” In: Luiz F. de Paula and Rogério Sobreira (org.) (2009). Política Monetária, Bancos Centrais e Metas de Inflação: Teoria e Experiência Brasileira. Rio de Janeiro: Ed. FGV.

Taylor, Alan M. and Taylor, Mark P. (2004). “The Purchasing Power Parity Debate”. NBER Working Papers Series 10607. Cambridge, Massachusetts. National Bureau of Economic Research.

UNCTAD (2011). "Global Imbalances: The choice of the exchange rate-indicator is key". UNCTAD Policy Briefs ${ }^{\circ} 19$. Geneva: United Nations Conference on Trade and Development. January 2011.

Williamson, John (1995). "Estimates of FEERs”. In John Williamson (ed.). Estimating Equilibrium Exchange Rates. Washington, DC: Institute of International Economics.

Williamson, John (2008). “Exchange Rate Economics”. Working Paper Series WP 08-3. Washington, D.C., Peterson Institute for International Economics.

\section{Appendix 1 \\ DESCRIPTION OF THE DATA SOURCE}

Actual real effective exchange rate - estimated by Brazil's Central Bank (http://www. bcb.gov.br).

Real GDP per capita in US Dollar - estimated by Brazil's Central Bank based on statistics on monthly real GDP in R B Brazilian Real (series $N^{\circ} .4383$ ) and transformed into US Dollar according to IPEAdata series of exchange rates. Population estimated by the Brazilian Institute of Geography and Statistics (IBGE) - http://www.bcb.gov.br

Terms of trade - estimated by FUNCEX- FUNCEX12_TTR12 (http://www.funcex. com.br)

Current Account Balance - Balance of Payments, Brazil's Central Bank (http://www. bcb.gov.br). br)

GDP in current US Dollar - Brazil's Central Bank (series no. 4; http://www.bcb.gov.

Short-term interest rate differential — difference between Brazil's Central Bank monthly interest rate series for SELIC (BCB Boletim/M.Finan. - BM_T JOVER12 - http://www. bcb.gov.br) and the US FED FUNDS monthly interest rate (IFS/IMF — IFS12_TJFFEUA12).

Net short-term capital flow - Balance of Payments, Brazil's Central Bank (http://www. bcb.gov.br)

Stock of international reserves - Brazil's Central Bank (series no. 3546; http://www. bcb.gov.br).

Brazil's risk premium (EMBI Brazil sovereign foreign currency) - Standard\&Poors monthl series. 